\author{
Anna Larenta \\ Wydział Filologiczny \\ Uniwersytet w Białymstoku \\ e-mail: anna.larenta@gmail.com \\ ORCID: 0000-0002-3589-138X
}

\title{
Grzybnia jako metafora w twórczości Olgi Tokarczuk
}

Grzyby, przez wiele wieków zaliczane do roślin, doczekały się własnego królestwa fungi ${ }^{1}$, położonego obok fauny i flory. Wybitnym badaczem tego królestwa jest Robert Hofrichter - austriacki zoolog, biolog, pisarz, dziennikarz, fotograf przyrody - autor Atlasu grzybów oraz Tajemniczego życia grzybów. Zainteresowany formami koegzystencji ludzi i grzybów, otwiera nowe obszary badawcze, a tym samym nowe dyskursy, takie jak biogeografia grzybów czy geografia mykologiczna ${ }^{2}$. Podstawą proponowanych przez niego badań jest nierozerwalny związek grzybów z konkretnymi miejscami ${ }^{3}$. Potwierdza to fakt, że wiedza o stanowiskach występowania, jak też umiejętność rozpoznawania poszczególnych gatunków, przekazywana jest z pokolenia na pokolenie. Zachowania społeczne związane z tradycją grzybobrania stały się także przedmiotem refleksji Rocha Sulimy, antropologa codzienności i pasjonata grzybobrania, który zauważa, że wiedza o miejscach występowania grzybów przeznaczona jest wyłącznie dla osób bliskich bądź darzonych zaufaniem ${ }^{4}$. Zresztą dostępne w Internecie, a tworzone przez grzybiarzy mapy

\footnotetext{
1 Funga, lub inaczej mykobiota to ogół wszystkich gatunków grzybów występujących na danym obszarze.

2 R. Hofrichter, Tajemnicze życie grzybów, przeł. B. Nowacki, M. Kilis, Warszawa 2017, s. $112-126$.

3 Tamże, s. 114.

4 R. Sulima, Grzyb a sprawa polska, rozm. A. Zawisza, „Przegląd” 2010, nr 39, https://www. tygodnikprzeglad.pl/grzyb-sprawa-polska/ [dostęp 10.12.2018].
} 
występowania poszczególnych gatunków grzybów ${ }^{5}$, także nie zdradzają „,rodzinnych łowisk".

Olga Tokarczuk w swoich utworach bardzo często tematyzuje grzyby, łącząc je z topografią konkretnego miejsca. Poszczególne gatunki bowiem wchodzą w symbiotyczny związek z roślinnością występującą na danym obszarze. Geograficznie uwarunkowana jest grzybnia, która w powieści Prawiek i inne czasy "rośnie pod całym lasem", a jej serce umiejscowione jest w lesie zwanym Wodenicą. W rozdziale Czas grzybni Tokarczuk pisze:

Głęboko pod ziemią, w samym środku Wodenicy, tętni wielki biały splątany kłąb plechy, który jest sercem grzybni. Stąd grzybnia rozpościera się na wszystkie strony świata. [...] Ludzie instynktownie omijają Wodenicę, chociaż nie wiedzą, że tu, pod spodem, pulsuje serce grzybni ${ }^{6}$.

Wodenica to las mroczny i zawsze wilgotny, przez bohaterów Prawieku uważany za nawiedzony. Jest on z całą pewnością tworem literackim, mającym jednak swoje pierwowzory w rzeczywistości. Nazwa Wodenica ${ }^{7}$, podobnie jak inne pojawiające się $\mathrm{w}$ powieści nazwy geograficzne, stanowi trop toponomastyczny ${ }^{8}$, pomimo, że pisarka określa powieść jako prozę kreacyjną, którą trudno zamknąć w ścisłych geograficznie granicach ${ }^{9}$. Serce grzybni, umieszczone $\mathrm{w}$ lesie obdarzonym własną nazwą, staje się bardziej realne, uwiarygodnione. Prawiek to centrum świata ludzkiego ${ }^{10}$, natomiast centrum świata grzybni leży w Wodenicy - miejscu, gdzie bierze ona swój początek, gdzie znajduje się jej serce, którego uderzenie następuje raz na osiemdziesiąt ludzkich lat [P, s. 115]. Elżbieta Rybicka, rozwijając koncepcję tropów toponomastycznych w literaturze, zwraca uwagę na znaczeniową dwukierunkowość nazw własnych, które mają charakter językowy i współtworzący semantykę wypowiedzi, a jednocześnie odsyłają do zewnętrznego pola odniesienia, którym, w przypadku Wodenicy, jest lokalna nazwa lasu. Rybicka podkreśla, że nazwy własne "są zarazem indeksami, jak i symbolami" ${ }^{11}$. Symboliczna

5 Zob. https://grzyby.pl/wystepowanie.htm [dostęp 11.12.2018].

6 O. Tokarczuk, Prawiek i inne czasy, Warszawa 2009, s. 114-115. Kolejne cytaty z tej powieści lokalizuję w tekście głównym, oznaczając je skrótem P.

7 Wodenica to nazwa części wsi Rzeczyca Sucha leżącej pod Sandomierzem, na OpenStreetMap prezentuje się jako teren zalesiony, https://www.openstreetmap.org/search?query=wode nica\#map=15/50.7159/21.7743 [dostęp 30.07.2018].

8 O tropach toponomastycznych pisze E. Rybicka w książce Geopoetyka. Przestrzeń i miejsce we wspótczesnych teoriach i praktykach literackich, Kraków 2014, s. 186.

9 O. Tokarczuk, Nie ma mnie jednej, "Sycyna” 1997, nr 24, s. 3.

10 W książce czytamy: „Prawiek jest miejscem, które leży w środku wszechświata” [P, s. 5].

11 E. Rybicka, Geopoetyka, s. 191. 
funkcja nazwy Wodenica ujawnia się $\mathrm{w}$ zestawieniu $\mathrm{z}$ chorwackim słowem vodenica, oznaczającym młyn, które może stanowić źródłosłów znajdującego się w Prawieku młyna wodnego należącego do Niebieskich - głównych bohaterów powieści.

W Prawieku $i$ innych czasach fascynację grzybami najintensywniej przeżywa Ruta, córka Kłoski - miejscowej wiedźmy. Ruta, poprzez imię oraz pochodzenie - jej ojcem jest arcydzięgiel [P, s. 44-48] - jest ściśle związana ze światem roślin, z natury współpracujących z grzybami. Owładnięta obsesją grzybów, wchodzi z nimi w niemal symbiotyczną relację.

Ruta kochała grzyby bardziej niż rośliny i zwierzęta. [...] Wiedziała, w których miejscach na powierzchnię ziemi wychodzi grzybnia, gdzie wyciąga swoje macki na świat. Kiedy znalazła prawdziwka czy kozaka, kładła się przy nim na ziemi i długo go obserwowała, zanim pozwoliła zerwać [P, s. 75].

Ruta jest nie tylko wytrawną grzybiarką, lecz także istotą wybraną i wtajemniczoną, która jako jedyna w Prawieku wie, gdzie znajduje się serce grzybni. Domyśliła się tego po najpiękniejszych muchomorach występujących w Wodenicy. Tylko ona zresztą dostąpiła zaszczytu usłyszenia grzybni:

Ruta kiedyś usłyszała życie grzybni. Był to podziemny szelest, który brzmiał niby głuche westchnienie, a potem słychać było delikatne potrzaskiwanie grudek ziemi, kiedy przepychała się między nimi nitka plechy. Ruta usłyszała uderzenie serca grzybni, które następuje raz na osiemdziesiąt ludzkich lat.

Od tej pory przychodzi $\mathrm{w}$ to wilgotne miejsce na Wodenicy i zawsze kładzie się na mokrym $\mathrm{mchu}^{12}$.

Bohaterka doświadcza grzybów cieleśnie, w sposób bardzo emocjonalny i ten pozawerbalny kontakt $\mathrm{z}$ odmiennym bytem, jakim jest grzybnia, ma $\mathrm{w}$ jej przypadku charakter obcowania z wyższą inteligencją. Podobne doświadczenie towarzyszy bohaterce-narratorce Domu dziennego, domu nocnego, będącej poniekąd alter ego autorki. Ekscentryczna kobieta, mieszkająca w okolicach Nowej Rudy, zbiera nie tylko kozaki i prawdziwki, jak miejscowi grzybiarze oferujący swoje zbiory za butelkę wina, lecz wszystkie grzyby, nawet te powszechnie uważane za niejadalne (flammulina, borowik ponury, purchawka czy muchomor). W powieści Dom dzienny, dom nocny czytelnik znajdzie nie tylko wiele literacko sportretowanych grzybów, ale także przepisy na krokiety z flammuliny, purchawki na słodko czy tort z muchomora (przepis na zakładce dołączonej do pierwszego wydania książki). Przepisy stanowią na-

12 Tamże, s. 115. 
wiązanie do powieści Laury Esquivel Przepiórki w płatkach róży, zaliczanej do klasyki realizmu magicznego. W Domu dziennym, domu nocnym narratorka próbuje wyjaśnić świat za pośrednictwem metafory grzybni. Sprzeciwia się dzieleniu grzybów na jadalne i trujące, ponieważ - jak twierdzi „,W świecie grzybów nic nie jest pewne" ${ }^{13}$. Tokarczuk proponuje bardziej złożoną, lecz według niej też bardziej adekwatną i lepiej oddającą różnorodność gatunkową, klasyfikację grzybów, stwierdzając: „Żadna książka o grzybach nie dzieli ich na piękne i brzydkie, na pachnące i cuchnące, na miłe w dotyku i niemiłe, na skłaniające do grzechu i na te, które rozgrzeszają" [s. 209].

Kryteria klasyfikacji grzybów, zaproponowane przez bohaterkę, odnoszą się głównie do sensorycznego i metafizycznego ich doświadczania, a co za tym idzie subiektywnego podziału. W Domu dziennym, domu nocnym grzyby przedstawione są bardzo zmysłowo, kiedy bohaterka podziwia ich wygląd, zwraca uwagę na smak i zapach, dotyka, a nawet słyszy jak rosną. Podczas sezonu grzybowego ogarnia ją grzybowa obsesja, niedająca się uzasadnić wyłącznie potrzebą przyrządzenia posiłku. Zwierza się więc: "Rano nie myślałam o niczym innym, tylko o grzybach. Nocą wydawało mi się, że słyszę jak rosną. [...] Dlatego nie mogłam spać" [D, s. 208]. Daleko idąca fascynacja grzybami prowadzi ją do fantazjowania o nich. Po stwierdzeniu: "Gdybym nie była człowiekiem, byłabym grzybem" [D, s. 51], bohaterka powieści stara się wyobrazić sobie własne życie jako grzyba, mającego zdolność oddziaływania na ludzi, ale też posiadającego władzę nad czasem.

Bohaterowie powieści z natury swojej przypominają grzyby, jednak nie $\mathrm{w}$ znaczeniu, jakie funkcjonuje $\mathrm{w}$ języku potocznym, pogardliwie przypisującym to miano człowiekowi staremu i zniedołężniałemu. W prozie Tokarczuk człowiek podobny do grzyba to ten, który posiada swoje konkretne miejsce, choć nie rządzi nim idea zakorzenienia. Podobna grzybowi jest między innymi Marta, główna bohaterka Domu dziennego, domu nocnego - sąsiadka narratorki. Jak grzyb wyrasta w określonym miejscu, wchodząc w lokalny ekosystem, a nawet wyznaczając jego porządek. Narratorka tak oto przedstawia czytelnikowi swoją sąsiadkę: „Jeżeli była tutaj Marta, wszystko znajdowało się na swoim miejscu" [D, s. 9]. Marta jest częścią ogólnego porządku świata, co podkreśla Przemysław Czapliński w recenzji książki: „Siła Marty polega na tym, że odnalazła ona rytm świata. Że raczej mieszka w czasie, niż go goni i że jej zgoda z trwaniem ma w sobie coś niepojętego, hipnotycznego i nieludzkiego" 14 .

13 O. Tokarczuk, Dom dzienny, dom nocny, Wałbrzych 1999, s. 209. Kolejne cytaty z tej powieści lokalizuję w tekście głównym, oznaczając je skrótem D.

14 P. Czapliński, Niezgoda na istnienie, "Tygodnik Powszechny” 1999, nr 8, s. 8. 
Nieludzka i hipnotyczna siła Marty, którą narratorka charakteryzuje jako mądrzejszą od siebie, ma z grzybami dużo cech wspólnych: pachnie wilgocią i podobnie jak grzyby wydaje się zimna, nieczuła, a nawet okrutna. Nie uzyskując żadnych informacji na temat tajemniczej sąsiadki, narratorka swoje wyobrażenia o niej buduje głównie na fantazjach: „Może są ludzie bez biografii, bez przeszłości i bez przyszłości, którzy zjawiają się innym jako wieczne teraz?" [D, s. 12]. Trwanie w wiecznej teraźniejszości przypomina omawianą w dalszej części wywodu zdolność grzybni do spowalniania czasu. Pomiędzy Martą - perukarką, a konkretnym grzybem - kanią czubajką zauważalne jest wyraźne podobieństwo:

Kania jest grzybem, który nie zna młodości. Jest stara już wtedy, gdy wychodzi z ziemi w postaci białego kołpaczka. Ma leciwe ciało, ciało staruszki; przypomina mi Martę. Chuda żylasta noga trzyma nad ziemią delikatny kapelusz, który przy dotknięciu wydaje się zawsze trochę ciepły [D, s. 209].

Marta, która „istniała tylko latem, zimą znikała” [D, s. 9] intryguje narratorkę swoją tajemniczością, ponieważ podobnie jak grzyb pojawia się tylko o określonej porze roku. Ponadto nie posiadając przeszłości, sprawia wrażenie kobiety starej od zawsze, przez co przypomina jakieś mityczne lokalne bóstwo.

W wyobrażeniu Tokarczuk podobieństwa między grzybami a ludźmi nie są jednostronne, bowiem nie tylko ludzie przypominają grzyby, ale też grzyby mają ludzkie cechy. Przykładem jest flammulina, której narratorka przypisuje ludzki, choć raczej zmysłowy niż rozumowy, sposób odbierania świata. Flammulinę, grzyb rosnący zimą, a przypominający człowieka, który urodził się nie w swojej epoce, pisarka charakteryzuje w następujący sposób:

Flammulina jest grzybem, który rośnie zimą. Od października do kwietnia żywi się martwymi drzewami. Pięknie pachnie i świetnie smakuje. Trudno jej nie zauważyć - jest żółta jak miód. Nikt jednak nie zbiera zimą grzybów. Ludzie umówili się, że grzyby zbiera się jesienią. Dlatego flammulina przypomina człowieka, który urodził się nie w swojej epoce, za późno, i wszystko wydaje mu się martwe, zastygłe; żyje w czasie, w którym dla jego gatunku skończył się świat. Widzi wokół siebie tylko ponury zimowy krajobraz, czasem prószy śnieg i pokrywa żółte kapelusze białymi koronkami. Widzi szczątki innych grzybów - pokryte białym nalotem zajączki o nogach osłabionych zgnilizną, padłe podgrzybki, wymiękłe od wilgoci huby [D, s. 49].

Świat obserwowany przez flammuline przedstawiony zostaje w sposób postapokaliptyczny. Wszystko, co widzi jest martwe i zastygłe, a obserwowane szczątki innych grzybów świadczą o jej ogromnym osamotnieniu. 
W Prawieku i innych czasach wyobraźnia autorki tworzy grzybnię przypominającą pierwotne, bezkształtne, lecz potężne bóstwo, posiadające nadludzką moc:

Nici grzybni mają potężną siłę i wciskają się między każdą grudkę ziemi, oplatają korzenie drzew i przytrzymują wielkie głazy $\mathrm{w}$ ich nieskończenie powolnym ruchu naprzód. Grzybnia podobna jest pleśni - biała, delikatna, zimna - księżycowa podziemna koronka, wilgotne mereżki plechy, śliskie pępowiny świata [P, s. 114].

Grzybnia przedstawiona jako biała, delikatna księżycowa koronka, kojarzy się z czymś kruchym, łatwo ulegającym zniszczeniu. Potrafi ona jednak powstrzymać ruch wielkich głazów niczym ostoja, podtrzymująca cały wszechświat, nadając mu ład i porządek. Tokarczuk odwołuje się $\mathrm{w}$ tym fragmencie do obecnej w wielu kulturach metafory Matki Ziemi, dawczyni życia, uosobienia płodności i macierzyństwa ${ }^{15}$. Autorka uzupełnia jednak to archetypiczne wyobrażenie o pępowinę-grzybnię. Dzięki niej Matka Ziemia przesyła swoim dzieciom niezbędne do życia składniki. Literackie wyobrażenie grzybni jako medium, znajduje potwierdzenie w książce Hofrichtera, który podkreśla, że korzenie nie są wystarczającym łącznikiem między roślinami a glebą. To strzępki grzybni bowiem są niezbędnym pośrednikiem umożliwiającym przepływ substancji chemicznych. Obieg informacji i różnorodnych substancji odżywczych odbywa się zarówno między roślinami a grzybnią, między roślinami a glebą, jak też między wieloma różnymi roślinami współpracującymi ze sobą. Jak twierdzi austriacki biolog, prawie 90\% roślin nawiązuje związki symbiotyczne $z$ grzybami ${ }^{16}$. Przekazują one drzewom pozyskane $\mathrm{z}$ gleby minerały, otrzymując $\mathrm{w}$ zamian cukier, witaminy, prowitaminy oraz tlen. To właśnie grzyby są twórcami podziemnej sieci, znanej jako Wood-Wide-Web lub internet drzew, dzięki której rośliny i grzyby komunikują się ze sobą ${ }^{17}$. Tokarczuk zwraca uwagę na występujące w przyrodzie rozwinięte mechanizmy współpracy:

Drzewa nigdy nie wypuszczają korzeni w czarną podziemną otchłań, w nicość, one rosną, rozprzestrzeniając się horyzontalnie, aż napotkają korzenie innego drzewa, a wtedy splątują się z nimi, jakby podawały sobie dłonie i tworzą $\mathrm{w}$ ten sposób jeden wielki podziemny organizm ${ }^{18}$.

\footnotetext{
15 M. Eliade, Sacrum a profanum. O istocie sfery religijnej, przeł. B. Baran, Warszawa 2008, s. 163.

16 R. Hofrichter, Tajemnicze życie grzybów, s. 15.

17 R. Macfarlane, The Secrets of Wood Wide Web, "The New Yorker", 7.08.2016, https://www. newyorker.com/tech/elements/the-secrets-of-the-wood-wide-web [dostęp 30.07.2018].

18 O. Tokarczuk, Czy tożsamość lokalna ma dziś sens?, "Gazeta Wyborcza" 15.09.2016, http://
} 
Idea sprawczości leży u podstaw nowej humanistyki, charakteryzując zwrot zookrytyczny, ekokrytyczny czy zwrot ku rzeczom. Zdaniem Ewy Domańskiej dominujący dotychczas dyskurs antropocentryczny ustępuje miejsca dyskursom nieantropocentrycznym, podejmującym problem sprawczości podmiotów nie-ludzkich. W książce Nekros. Wprowadzenie do ontologii martwego ciała badaczka zauważa, że uznanie artefaktów za aktywne podmioty stanowi odejście od rozumienia sprawczości jako związanej z ludzką intencjonalnością i odwołując się do koncepcji siatki (networku) ${ }^{19}$, obecnej w teoriach Alfreda Gella oraz Burno Latoura, podejmuje próbę zredefiniowania kategorii sprawczości:

$\mathrm{W}$ takim ujęciu ważny jest nie tyle sprawca/aktor i jego status, ile jego miejsce w sieci relacji, a także badanie połączeń i ich zmian (rozpadania się związków i ponownego ich splatania). Sprawstwo zaś to wypadkowa działania wielu aktorów - czynników ludzkich i nie-ludzkich, które same w sobie są podmiotami zbiorowymi (zbiorowiskami, asamblażami) ${ }^{20}$.

Z perspektywy idei sprawczości interesują Domańską także grzyby, nie tylko jako destruenci, rozkładający martwą materię organiczną, lecz także jako organizmy tworzące złożone sieci zależności. Grzyby, podobnie jak martwe ciała, mają ważny wkład w tworzenie i rozwój „ludzkiej historii kulturowej, jak i naturalnej" 21. Badaczka powołuje się na Annę L. Tsing, która udowadnia, że grzyby, nie poddające się ludzkiej władzy, mają ogromny wpływ na rozwój cywilizacji ${ }^{22}$.

Domańska proponuje wyjście poza „binarną opozycję w rozumieniu tego, co uważane jest za żywe i za martwe" ${ }^{23}$, korespondując tym samym z literackim obrazem grzybni jako „życia śmierci” przedstawionym przez Tokarczuk:

Grzybnia nie jest ani rośliną, ani zwierzęciem. Nie potrafi czerpać siły ze słońca, bo jej natura obca jest słońcu. Nie ciągnie jej do ciepłego i żywego, bo jej natura nie jest ani ciepła, ani żywa. Grzybnia żyje dzięki temu, że wysysa resztki soków $\mathrm{z}$ tego, co umiera, co się rozkłada i wsiąka w ziemię. Grzybnia jest życiem śmierci, życiem rozkładu, życiem tego, co umarło ${ }^{24}$.

wyborcza.pl/1,87648,20696186,czy-tozsamosc-lokalna-ma-dzis-sens-olga-tokarczuk.html [dostęp 30.07.2018].

19 O koncepcji siatki por. także: K. Abriszewski, Czy teoria aktora sieci daje narzędzia do ekokrytyki, „Teksty Drugie” 2018, nr 2, s. 369-392.

20 E. Domańska, Nekros. Wprowadzenie do ontologii martwego ciała, Warszawa 2017, s. 63.

21 Tamże, s. 61.

22 Por. A.L. Tsing, The Mushroom at the End of the World, Princeton 2015.

23 E. Domańska, Nekros, s. 61.

24 O. Tokarczuk, Prawiek $i$ inne czasy, s. 114. 
Pisarka podkreśla silną relację pomiędzy elementami ekosystemu, w którym nic nie jest zbędne. To, co umiera staje się życiem, przechodząc $w$ inną jego formę. Towarzyszący grzybom rozkład jest zjawiskiem pozytywnym, gdyż nosi w sobie cechy rekreacji, śmierć natomiast - mówiąc słowami Domańskiej - , jest zdolnością, którą powinniśmy chronić jako zdobycz długiego trwania na Ziemi i warunek przetrwania" ${ }^{25}$. Tokarczuk dostrzega wage śmierci ${ }^{26}$, szczególnie $\mathrm{w}$ dobie powszechnego kultu życia, charakteryzującego nasz krąg kulturowy. Autorka Domu dziennego, domu nocnego zauważa, że „śmierć jest momentem bardziej naturalnym niż życie” ${ }^{27}$. Każde życie opiera się bowiem na śmierci, a grzyby jako destruenci odgrywają szczególną rolę $\mathrm{w}$ procesie rozkładu materii oraz tworzenia jej nowych form. Bohaterka powieści, marząc o byciu grzybem, wyraża swoje pragnienie przynależności do systemu, a więc do tego, co wieczne i trwałe. Wejście w rolę grzyba (nawet hipotetyczne) jest jej sposobem na oswojenie śmierci i przemijania:

Rosłabym na przewróconych drzewach, mrocznie i złowrogo, zawsze w ciszy, rozczapierzonymi grzybowymi palcami ssałabym z nich resztki słońca. Rosłabym na tym, co umarło. Przenikałabym tę martwotę do czystej ziemi - tam moje grzybowe palce by się zatrzymywały. Byłabym mniejsza od drzew i krzaków, ale wyrastałabym ponad jagodniki. Byłabym nietrwała, lecz jako człowiek też przecież jestem nietrwała. Nie interesowałoby mnie słońce, nie wodziłabym za nim wzrokiem, nie czekałabym już nigdy, kiedy wzejdzie. Tęskniłabym tylko do wilgoci, wystawiałabym moje ciało do mgieł i deszczu, skraplałabym na sobie mokre powietrze. Nie odróżniałabym nocy od dnia, bo po co? [...]

Nigdy nie miałabym w sobie żadnego lęku, nie bałabym się śmierci. Cóż to jest śmierć, myślałabym, jedyne, co ci mogą zrobić, to oderwać cię od ziemi, poszatkować, usmażyć i zjeść ${ }^{28}$.

Grzyby w twórczości Tokarczuk to byty inteligentne, tworzące sieci zależności, komunikujące się ze sobą oraz stanowiące wzór kooperacji. Pisarka, poza wymienionymi powyżej cechami, przypisuje im także moc magiczną. Postrzega grzybnię jako byt totalny, obalający przeświadczenie o ludzkiej wyjątkowości i aby oddać odmienność grzybowego bytu, proponuje nowe pojęcie: „grzybość" 29 . Wykorzystana przez nią końcówka -ość wskazuje na nazwę abstrakcyjnej cechy. Zgodnie z definicją słownikową „przymiotniki relacyjne

\footnotetext{
25 E. Domańska, Nekros, s. 45.

26 Warto zaznaczyć, że Tokarczuk w swoich utworach wyprzedza rozwój badań dotyczących ontologii martwego ciała.

27 O. Tokarczuk, Dom dzienny, dom nocny, s. 166.

28 Tamże, s. 53.

29 Tamże.
} 
mogą być podstawami formacji na -ość tylko wtedy, kiedy są użyte w znaczeniu przenośnym" ${ }^{30}$. Jeśli więc forma "grzybość" byłaby wyłącznie nazwą cechy, musiałaby zostać utworzona od przymiotnika relacyjnego "grzybowy", który odnosi się jednak wyłącznie do smaku grzybowego. W takim przypadku poprawna forma brzmiałaby "grzybowość". Z całą pewnością więc pojęcie "grzybość" jako nazwa abstrakcyjnej cechy zostało użyte w znaczeniu przenośnym. Utworzony przez Tokarczuk neologizm, zyskując zupełnie nowe pola odniesień, może funkcjonować analogicznie do słowa „ludzkość". "Grzybość" rozumiana może być zatem jako byt społeczny, uwznioślony poprzez nadanie cech przypisywanych wyłącznie ludziom. Analogii między grzybnią a ludzkością jest wiele, Tokarczuk jednak unika upraszczających porównań. W Prawieku i innych czasach zauważa, że prawdziwa, podziemna grzybnia jest nieśmiertelna [P, s. 75] ${ }^{31}$, więc pojedynczy grzyb podobnie jak człowiek umiera, grzybnia - jak ludzkość trwa. Grzybnia, tworząca „w ziemi, pod miękkim poszyciem, pod trawą i kamieniami, plątaninę cienkich niteczek, sznurków i kłębków, którymi omotuje wszystko"32, staje się metaforą epistemologiczną, wokół której nawarstwiają się różne znaczenia. Znajdując się na granicy ukrytego, tajemniczego wnętrza ziemi i dostrzegalnego gołym okiem świata zewnętrznego, jest łącznikiem pomiędzy nimi.

Roch Sulima postrzega grzybobranie jako błądzenie w zaświatach: „W naszej starej tradycji, dziś już mało czytelnej, grzyby wiążą się z czymś, co przypomina wędrówkę po śnie, po innym świecie" ${ }^{\prime 3}$. Rosnące nocą grzyby mają coś z rzeczywistości snu, nie rosną bowiem na oczach ludzi, którzy je dopiero znajdują, lecz pod ich nieobecność. Sulima twierdzi, że grzybobraniu sprzyja świt, czyli przełom nocy i dnia, który to moment nazywa "szczególną metaforą granicznej przemiany", natomiast popołudniowe wyjścia na grzyby według niego "przypominają sztucznie odtwarzany rytuał” ${ }^{34}$. Bohaterka Domu dziennego, domu nocnego, dywagując o wejściu w rolę grzyba, także podkreśla znaczenie pory dnia: „Rosłabym tylko w najważniejszych momentach dnia i nocy - o świcie i o zmierzchu, gdy wszystko inne zajęte jest budzeniem się albo zapadaniem w sen" 35 .

Do grzybów należą dwa najbardziej tajemnicze momenty doby, świt i zmierzch, znajdujące się pomiędzy dniem i nocą. Ciekawym zjawiskiem,

\footnotetext{
30 Nowy słownik poprawnej polszczyzny, red. A. Markowski, Warszawa 2002, s. 1607.

31 O. Tokarczuk, Prawiek $i$ inne czasy, s. 75.

32 O. Tokarczuk, Dom dzienny, dom nocny, s. 114.

33 R. Sulima, Grzyb a sprawa polska.

34 Tamże.

35 O. Tokarczuk, Dom dzienny, dom nocny, s. 51-52.
} 
któremu przypisywano dawniej ogromne znaczenie, są powstające $\mathrm{z}$ owocników grzybów tzw. „,czarcie koła”. Grzyby w ogóle uważane są za magiczne, gdyż obok miodu i zboża należą do potraw rytualnych, bez których nie może się odbyć np. wieczerza wigilijna ${ }^{36}$. O symbolicznym i magicznym znaczeniu grzybów świadczy ich szerokie zastosowanie w praktykach szamańskich na całym świecie. Hofrichter twierdzi, że muchomory czerwone stanowią „najstarszy środek zmieniający stan świadomości, czyli najstarszy narkotyk ludzkości" ${ }^{37}$. Szamani wykorzystywali halucynogenne właściwości grzybów nie tylko do wprawienia się $\mathrm{w}$ stan transu narkotycznego i doświadczenia wizji, ale też do leczenia ludzi ${ }^{38}$. Grzyby nie są więc wyłącznie pośrednikami między roślinami czy między roślinami a glebą, ale też medium między człowiekiem a sacrum. W powieści Prawiek $i$ inne czasy to właśnie muchomory zbliżają Rutę do sfery sacrum:

Tego roku, gdy boską obecność czuło się szczególnie wyraźnie w całym Prawieku, muchomory pojawiły się już na początku lipca i zarastały brzozowe polanki czerwonymi kapeluszami. Ruta skakała między nimi, ale tak, żeby ich nie zniszczyć. Potem kładła się między nie i zaglądała im pod czerwone sukienki. [...]

Muchomory są strażnikami grzybni. Ruta kładzie się na ziemi między nimi i ogląda od spodu ich spienione, śnieżnobiałe halki [P, s. 75].

W literackim Prawieku występowanie muchomorów w dużej ilości pokrywa się z odczuwalną przez mieszkańców obecnością boga. Są one także strażnikami grzybni i doprowadzają Rutę do jej serca, mieszczącego się w Wodenicy. Obdarzone niezwykłą inteligencją potrafią rozpoznać i ocenić ludzkie intencje oraz uczucia. W Prawieku i innych czasach powieściową szamanką jest matka Ruty - Kłoska. Kobiety żyją blisko natury, w zniszczonym domu w środku lasu, z dala od wsi, ludzi i cywilizacji, żyją w zgodzie z naturą, dzięki czemu korzystają z jej darów i dobrodziejstw. Do Kłoski ukradkiem przychodzą mieszkańcy pobliskich wsi z prośbą o wyleczenie, chociaż otwarcie nikt się do tego nie przyznaje. Wszyscy chcą korzystać z jej wiedzy, która nie wypływa z książek, lecz z mądrości, jaką daje szacunek do przyrody i obcowanie z nią. Kłoska zna właściwości ziół i grzybów, a wiedzę tę przekazuje systematycznie swojej córce Rucie. Ta w rozmowie z Izydorem wykazuje się znajomością muchomorów, wykraczającą poza atlas grzybów, z którego Izydor uczy ją czytać:

\footnotetext{
36 R. Sulima, Grzyb a sprawa polska.

37 R. Hofrichter, Tajemnicze życie grzybów, s. 64.

38 Znaną na całym świecie szamanką, uzdrawiającą z pomocą grzybów była mazatecka szamanka Maria Sabina, żyjąca w latach 1894-1985. Zob. film http://szyszka.art.pl/szamani.html.
} 
Uważaj, są trujące - ostrzegał ją Izydor, ale Ruta się śmiała.

Pokazywała Izydorowi różne muchomory, nie tylko czerwone: białe, zielonkawe albo takie, które udawały inne grzyby, na przykład pieczarki.

- Moja mama je zjada.

- Kłamiesz, są śmiertelnie trujące - oburzał się Izydor.

- Mojej mamie nie szkodzą. Ja też będę mogła je kiedyś jeść.

- Dobra, dobra. Uważaj na te białe. Są najgorsze [P, s. 75].

W prozie Tokarczuk muchomor nie jest zły, ponieważ nie ma złych intencji, charakteryzujących tylko ludzi. Kłoska z Prawieku i innych czasów oraz bohaterka Domu dziennego, domu nocnego, jedzą muchomory ${ }^{39}$, lecz czynią to świadome ryzyka. Odpowiedzialność za ewentualne zatrucie spoczywa wyłącznie na nich. Bohaterka Domu dziennego, domu nocnego zachwyca się nawet ich smakiem:

Były zbyt smaczne, żeby mogły być trujące. Czekałam całą noc, nawet dwie, trzy noce, bo objawy zatrucia mogły nastąpić bardzo późno. Nad ranem patrzyłam w jaśniejszą plamę okna z krzyżem pośrodku. Na stole leżał kluczyk od samochodu. Grzyb nie chciał mnie zabić. [...]

- Dlaczego coś miałoby chcieć mojej śmierci? - pytałam go. - Czy jestem aż tak ważna, żeby cokolwiek chciało mnie zabić? [D, s. 210]

Śmiertelne sprawstwo grzybów jest częścią naturalnego porządku, a ludzie niekiedy wykorzystują je do realizacji niecnych planów. Bohaterem opowiadania Przetwory ze zbioru Opowiadania bizarne jest pięćdziesięcioletni bezrobotny mężczyzna, który uciekając przed pracą i odpowiedzialnością, pozostaje na utrzymaniu matki aż do jej śmierci. Gdy zostaje sam, znajduje duże zapasy przygotowanych przez matkę przetworów, pozwalających przeżyć synowi, poświęcającemu się głównie piciu piwa oraz oglądaniu meczów w telewizji. Zjada przy tym zawartość słoików, a między nimi także tego z błędem na etykiecie: "Grzypki marynowane, 2005”. Owe "grzypki” są jego ostatnim posiłkiem i jak można wnioskować z błędu na etykiecie, zamarynowanie trujących grzybów nie było pomyłką kobiety, lecz rodzajem zemsty zza grobu lub zabójstwem z miłości. Błąd w zapisie (podobnie jak sznurówki w occie i gąbka w pomidorach także znajdujące się wśród przetworów) był ostrzeżeniem, które mężczyzna zignorował.

Zamieszkiwanie $\mathrm{w}$ pobliżu lasu daje możliwość korzystania $\mathrm{z}$ jego dobrodziejstw, w tym także grzybów, które bardzo często, jako główne pożywienie, pomagają przetrwać trudne czasy. Ludzie mają natomiast skłonność

39 Niektóre gatunki muchomorów nie posiadają toksycznych substancji, należą więc do jadalnych (np. muchomor cesarski, czy czerwieniejący), jednak nie ma powszechnej praktyki jedzenia ich. 
do okazywania lasowi niewdzięczności, jak było w przypadku Misi, jednej z bohaterek Prawieku i innych czasów, wyrywającej grzyby razem z mchem i darnią - żeby nie rosły. Tokarczuk często pokazuje codzienne sytuacje i z pozoru naturalne zachowania bohaterów jako działania w gruncie rzeczy opierające się na przemocy międzygatunkowej. Bohaterka Domu dziennego, domu nocnego zauważa przemoc nie tylko w stosunku do zwierząt, ale też innych organizmów żyjących, w tym właśnie grzybów:

trzeba wziąć do ręki nóż i ciąć ich miękkie, dziecinne ciała, odcinać im kapelusze i nabijać je na ostrza tarniny, żeby schły. Kolczaste gałązki z ukrzyżowanymi na nich kapeluszami całą jesień podpierały nasz dom [D, s. 208].

Grzyby mają dziecinne ciała, są miękkie i delikatne, pełnią rolę niewinnej ofiary, ukrzyżowanej przez główną bohaterkę, opisującą działanie człowieka poprzez nagromadzenie wyrazów związanych z przemocą: nóż, ciąć, odcinać, nabijać, ostrza, kolczaste, ukrzyżowane. Niewątpliwe poczucie winy $\mathrm{z}$ powodu własnego postępowania idzie $\mathrm{w}$ parze $\mathrm{z}$ koniecznością suszenia grzybów ponabijanych na rozwidlające się gałązki tarniny, który to zwyczaj potwierdza Ewa Referowska-Chodak, analizując związane z grzybami polskie tradycje ludowe ${ }^{40}$.

Grzyby w literackich światach Tokarczuk nie są bezbronnymi ofiarami, chociaż nie mają „pazurów, szybkich nóg, zębów i rozumu” [D, s. 51], posiadają nadnaturalne zdolności hipnotyzowania. Potrafią także panować nad czasem. W wyobraźni bohaterki Domu dziennego, domu nocnego jej egzystencja jako grzyba wyglądałaby następująco:

Miałabym tę samą zdolność co wszystkie grzyby - chowania się przed wzrokiem ludzi przez wprowadzanie w ich płochliwe myśli zamętu. Grzybiarze przechodziliby nade mną sennie z oczami wlepionymi przed siebie $\mathrm{w}$ barwne, migotliwe obrazy ze słońca i liści. Trzymałabym na uwięzi ich nogi, plątałabym je w ściółkę i zeschnięte kępy mchu. $Z$ dołu widziałabym lewą, wewnętrzną stronę ich kurtek. Godzinami z wyrachowaniem trwałabym bez ruchu, ani nie rosłabym, ani nie starzała się, aż do lodowatego przekonania, że mam władzę nie tylko nad ludźmi, ale i czasem [D, s. 51].

Grzyby potrafią zapanować nad ludźmi w nieuświadomiony przez nich sposób, poddając ich hipnotycznej władzy. Zdolność ta jest mechanizmem obronnym grzybów, dającym im władzę nie tylko nad człowiekiem, ale także nad

40 E. Referowska-Chodak, Ludowe zwyczaje związane z grzybami w Polsce, „Studia i Materiały CEPL w Rogowie" 2015, z. 44/3, s. 205. 
czasem, który człowiek może jedynie mierzyć, a nie zmieniać. Grzyby istnieją poza czasem, potrafią nim manipulować, dlatego sprawiają wrażenie istot należących do innego wymiaru, odmiennego porządku. Do swoich tajemnic dopuszczają tylko wybrane osoby. Przykładem jest Ruta, która dzięki grzybom doświadcza spowolnienia świata:

Od tej pory przychodzi $w$ to wilgotne miejsce na Wodenicy i zawsze kładzie się na mokrym mchu. Kiedy leży dłużej, zaczyna czuć grzybnię jeszcze inaczej - grzybnia bowiem spowalnia czas. Ruta zapada w sen-nie-sen i widzi wszystko w zupełnie odmienny sposób. Widzi pojedyncze podmuchy wiatru, pełen powolnej gracji lot owadów, płynne ruchy mrówek, cząsteczki światła, które osiadają na powierzchni liści. Wszystkie wysokie dźwięki - trele ptaków, piski zwierząt - zmieniają się $\mathrm{w}$ buczenia i dudnienia i suną tuż przy ziemi jak mgła. Rucie wydaje się, że leży tak godzinami, choć minęła ledwie chwila. Tak grzybnia bierze $\mathrm{w}$ posiadanie czas [P, s. 115].

Wodenica, w której znajduje się serce grzybni, obfituje $\mathrm{w}$ halucynogenne muchomory, toteż doznania Ruty można traktować jak wizję narkotyczną. Zdzisław Ryn, przytaczając relacje osób, które przeżyły trans ekstatyczny pod wpływem grzybów podczas leczniczych praktyk szamańskich w Meksyku, zauważa, że spożycie grzybów halucynogennych wywołuje między innymi właśnie zaburzenie poczucia czasu i przestrzeni ${ }^{41}$.

Metafizyka grzybów ujawnia się także w historii Franza Frosta, budowniczego domu, w którym zamieszkuje narratorka Domu dziennego, domu nocnego. Frostowi udało się zrealizować wszystko, co według patriarchalnego porządku powinien zrobić każdy mężczyzna: zbudował dom, spłodził syna i posadził drzewo. Żył jednak w nieustannym strachu przed wpływem obcej planety, gdyż - jak twierdził - śnił nieswoje, koszmarne sny. Sny, które stanowią istotną część życia wszystkich bohaterów powieści, odgrywają ważną rolę także w historii Frosta. Od narodzin syna prześladuje go następujący sen:

na stole leżą czerwone muchomory. Jego żona smaży je na wielkiej patelni i wkłada w bezbronne usta dziecka. A on na to patrzy i nie ma w nim żadnej myśli, nic go nie ostrzega przed śmiercią. Dziecko umiera, staje się małe jak laleczka, a on niesie je do ogrodu i zakopuje w dole, nagie, różowe ciało [D, s. 123].

Nie jest to jedyne ostrzeżenie, które Franz otrzymał przed nadchodzącą tragedią. Pewnego dnia zdarzyło się coś symptomatycznego - $\mathrm{w}$ ich domu pojawił się Ktoś. Sobowtór ich synka przyszedł "od strony słońca” i zapytał

41 Z.J. Ryn, Grzyby ułatwiajace kontakt z bogami, https://kultura.onet.pl/fragmenty-ksiazek/ grzyby-ulatwiajace-kontakt-z-bogami/ltd326g. 
o swojego brata. Chłopcy spędzili dzień na zabawie, po południu zaś syn Frosta wrócił zmęczony do domu, natomiast jego sobowtór już się nie pojawił. Postać Dopplegangera ${ }^{42}$ jest nie tylko motywem literackim ${ }^{43}$, lecz konstruktem kulturowym wywodzącym się z mitów, legend i religii ${ }^{44}$. Spotkanie własnego sobowtóra (zazwyczaj będącego negatywną częścią , ja") miało być złą wróżbą i zapowiedzią rychłej śmierci ${ }^{45}$. Tak jest też w przypadku syna Frosta, który wkrótce po tym niezwykłym spotkaniu umiera. W rodzicach chłopca twarz sobowtóra budzi niepokój, jest daleka, straszna, chociaż identyczna z twarzą ich syna. Odmienny stosunek do swojego podwojonego "ja” ma chłopiec, który całuje go na przywitanie i chętnie się z nim bawi. Dziecko, posiadające zupełnie inną wrażliwość niż dorosły nie boi się śmierci, nie reaguje więc także negatywnie na swojego sobowtóra, który nie jest zły, lecz jest właśnie ostrzeżeniem przed prawdziwie złym bratem bliźniakiem:

na cienistych skrajach łąk wyrasta czasami pieczarkowy sobowtór. Muchomor wiosenny, brat albinos muchomora sromotnikowego, samotnik grubą nogą wrośnięty $\mathrm{w}$ poszycie, łąkowa buława śmierci. Pachnie słodko: obserwuje pieczarkowe stada z daleka. Wilk w owczej skórze [D, s. 127].

Muchomor wiosenny z historii Frosta jest wyjątkiem wśród przedstawionych wcześniej grzybów (nawet tych niejadalnych) ze względu na złe intencje, które stara się ukryć. Grzyb ten jest scharakteryzowany poprzez podobieństwo do pieczarki, która $\mathrm{z}$ kolei $\mathrm{w}$ zestawieniu $\mathrm{z}$ muchomorem wiosennym jest przestawiona w sposób wyidealizowany:

Pieczarka jest grzybem miłym w dotyku, lubi pieszczotę ludzkich palców. Pocierana biała skórka pachnie anyżkiem. Różowe albo kawowe blaszki przypominają płatki kwiatu. Pieczarkę ma się ochotę dotykać i pieścić, zanim się ją posieka i wrzuci na patelnię. Poza tym pieczarka jako jeden z niewielu grzybów jest ciepła. Garnie się do ludzkiego ciała [D, s. 126].

Grzyb, który jest ciepły, lubi pieszczotę ludzkich palców, „garnie się do ludzkiego ciała", jest miły w dotyku, stanowi poniekąd zaprzeczenie opisanej przez Tokarczuk "grzybości”. "Charakter" pieczarki stanowi jednak

42 Pochodzący z języka niemieckiego termin Doppleganger, został wprowadzony przez pisarza Johanna Paula Friedricha Richtera, obecnie używany jest w wielu językach jako uniwersalne określenie sobowtóra.

${ }^{43}$ Motyw sobowtóra pojawia się między innymi w książkach: F. Dostojewski Sobowtór, E.T.A Hoffmann Diable eliksiry, H.Ch. Andersen Cień, E.A. Poe William Wilson, Ligeia, Upadek domu Usherów, Metzengerstein, Beczka Amontillado.

44 M. Živković, The Double as the "Unseen" of Coulture: toward a Definition of Doppelganger, „Facta Universitatis. Linguistics and Literature” 2000, nr 7, s. 121-128.

45 Por. hasło „sobowtór” w: W. Kopaliński, Słownik mitów i tradycji, Lublin 1997, s. 1203. 
wyraźny kontrast dla śmiertelnie niebezpiecznego sobowtóra: muchomora wiosennego. Ryszard Handke w tekście poświęconym semiotyce grzybobrania posługuje się terminem językoznawczym, aby zwrócić uwagę na specyficzną relację tych dwóch grzybów: „Kiedy młode pieczarki mają jeszcze białe blaszki, są „homonimami" niebezpiecznych trucicieli" ${ }^{46}$. Grzyby odczytywane jako znaki mogą być wieloznaczne, czasami różnią się tylko jedną cechą, $w$ tym jednak konkretnym przypadku są identyczne, jak to ma miejsce $\mathrm{w}$ przypadku przytoczonych przez badacza homonimów. Pomimo identycznej formy, homonimy mają odmienne znaczenie, w przypadku grzybów to odmienne znaczenie decyduje o życiu lub śmierci, opiera się bowiem na opozycji: jadalny/niejadalny. Maria Janion, analizując zagadnienie sobowtóra, zwraca uwagę właśnie na charakterystyczne dla niego rozdwojenie, na sprzeczną , ,jedność pierwiastków najwyższych i najniższych, Dobra i Zła, świadomości i podświadomości, ciała i duszy" ${ }^{47}$. Syn Frosta wykazuje się zdecydowanie lepszą intuicją niż jego rodzice, nie chce jeść grzybów, wśród których znalazł się muchomor, jednak zostaje do tego namówiony przez nieświadomą zagrożenia matkę. Tragedii można było zapobiec pod warunkiem właściwego zinterpretowania poprzedzających ją znaków.

Ewa Domańska podkreśla zasługi Anny L. Tsing, która wprowadziła do humanisyki kategorię grzybni, rozszerzając ideę kłącza opisaną przez Deleuze'a i Guattariego ${ }^{48}$. We współczesnym myśleniu filozoficznym można zatem wyodrębnić bliskie sobie metafory: grzybni i kłącza, których podstawą jest przekonanie o niemożliwości dychotomicznego podziału świata, opartego $\mathrm{w}$ istocie na złożoności wzajemnych relacji - połączeń. Tsing podkreśla, że podobnie jak grzybnia rozpoczyna swoją pracę długo przed pojawieniem się grzybów, również powstanie jej książki, będącej niczym owocnik grzybni - grzyb, zależało od pracy całego zespołu. Idea kłącza, oddająca fragmentaryczny i wieloraki obraz świata, powstała w opozycji do takiej jego wizji, jaką oddaje metafora korzenia i systemu korzonkowego. Kłącze, przerwane w dowolnym miejscu, nadal będzie się rozrastać. Linie kłączy, odnoszące się jedne do drugich, unieważniają upraszczający obraz dualizmu oraz ideę centrum ${ }^{49}$. Tsing, proponując kategorię wyobraźni mykologicznej, przedstawia ją roboczo jako wielowymiarową praktykę, opierającą się na wielości. Złożony, niestabilny współczesny świat, który rozpada się na wiele kawałków,

\footnotetext{
46 R. Handke, Pejzaż semiotyczny grzybobrania, "Teksty” 1978, nr 1, s. 224.

47 M. Janion, Tajemnica sobowtóra, w: tejże, Romantyzm i jego media, Prace wybrane, t. 4, Kraków 2001, s. 474-482.

48 G. Deleuze, F. Guattari, Tysiac plateau, red. J. Bednarek, Warszawa 2015.

49 Tamże.
} 
bliższy jest idei grzybni, mającej tę przewagę nad kłączem, że bardzo dobrze radzi sobie $\mathrm{w}$ środowisku zdegradowanym przez człowieka, pozornie martwym. Ważnym aspektem metafory grzybni, odróżniającym ją od kłącza, jest idea współpracy przynoszącej korzyść wszystkim zaangażowanym podmiotom, spośród których, każdy daje coś z siebie, otrzymując coś w zamian. Tsing mówi więc o działaniach opartych na współpracy, a nie rywalizacji prowadzącej, jak podkreśla, do zawłaszczania wyników cudzej pracy ${ }^{50}$. Myślenie zdominowane przez obraz grzybni bliskie jest także Hofrichterowi, który obserwując grzyby rozwija hipotezę, że życie na Ziemi powstało właśnie $\mathrm{w}$ wyniku międzygatunkowej współpracy i bez niej nie byłoby możliwe ${ }^{51}$. Warto zauważyć, że Tokarczuk wykorzystała grzyby jako temat literacki, aby zbudować nad nim, długo przed Tsing i Hofrichterem, epistemologiczną metaforę grzybni jako narzędzia interpretacji w ramach humanistyki nieantropologicznej.

Wyobraźnia oparta na systemie grzybni warunkuje także strukturę dzieł Tokarczuk, wśród których wyróżniają się Bieguni, powieść o nielinearnej fabule, fragmentaryczna, składająca się z wielu równorzędnych części. Pisarka, nazywając Biegunów „powieścią konstelacyjną”, przyczyniła się do powstania nowego gatunku literackiego, który szczególnie w Wielkiej Brytanii zyskał swoje miejsce w literaturoznawstwie. Claire Armitstead na łamach „The Guardian” pisze o „konstelacyjnym” stylu polskiej pisarki, zapoczątkowanym w Domu dziennym, domu nocnym ujawniającym się w patchworkowej budowie powieści. Dziennikarka, powołując się na rozmowę z Tokarczuk, proponuje rozumieć „powieść konstelacyjną” poprzez odniesienie do metafory astronomicznej. Jak zauważa, starożytni patrzyli na gwiazdy i znajdowali sposoby ich pogrupowania, a następnie odnosili je do kształtów stworzeń lub postaci. Powieść konstelacyjna natomiast rzuca historie, eseje i szkice na orbitę, pozwalając wyobraźni czytelnika na uformowanie ich w znaczącą całośćs2. W jednym z wywiadów, dotyczących Biegunów, Tokarczuk przyznaje:

Każdy recenzent zauważa w tej książce coś innego, wyciąga inne wątki i składa je w inną całość. Takie było zresztą założenie jej formy - powieści konstelacyjnej, jak ją sobie nazwałam. Wątki w niej zawarte, motywy, idee są pretekstem do ustanowienia własnego porządku czytelniczego. Ma zadziałać jak test projekcyjny - rzutujemy na nią własne sensy ${ }^{53}$.

50 A.L. Tsing, The Mushroom at the End of the World, Princeton 2015.

51 R. Hofrichtr, Tajemnicze życie grzybów, s. s. 36-37.

52 C. Armitstead, Olga Tokarczuk: "I was very naïve. I thought Poland will be able to discuss the dark areas of our history", „The Guardian” 2018, 20 Apr, https://www.theguardian.com/books / 2018/apr/20/olga-tokarczuk-interview-flights-man-booker-international [dostęp 12.12.2018].

53 O. Tokarczuk, W naszym świecie granica między fikcją a faktami staje się coraz bardziej ptynna, 
Powieści Olgi Tokarczuk składają się z różnych historii, które łączą się ze sobą, korespondują, lecz żadna $\mathrm{z}$ nich nie wybija się do roli "głównego wątku". Czytelnik może książkę traktować z pewną swobodą, niewymagającą linearnego czytania od początku do końca. Powieść można czytać fragmentarycznie, chodząc po rozdziałach w sposób dowolny, niczym po liniach kłączy czy też nitkach grzybni.

\section{Bibliografia}

Abriszewski Krzysztof (2018), Czy teoria aktora sieci daje narzędzia do ekokrytyki, „Teksty Drugie", nr 2, s. 369-391.

Armitstead Claire (2018), Olga Tokarczuk: „I was very naïve. I thought Poland will be able to discuss the dark areas of our history", „The Guardian”, 20 Apr, https://www.the guardian.com/books/2018/apr/20/olga-tokarczuk-interview-flights-man-book er-international.

Czapliński Przemysław (1999), Niezgoda na istnienie, „Tygodnik Powszechny”, nr 8, s. 8.

Deleuze Gilles, Guattari Félix (2015), Tysiac plateau, red. J. Bednarek, Warszawa: Fundacja Nowej Kultury Bęc Zmiana.

Domańska Ewa (2017), Nekros. Wprowadzenie do ontologii martwego ciała, Warszawa: PWN.

Eliade Mircea (2008), Sacrum a profanum. O istocie sfery religijnej, przeł. B. Baran, Warszawa: Wydawnictwo Aletheia.

Handke Ryszard (1978), Pejzaż semiotyczny grzybobrania, „Teksty”, nr 1, s. 219-231.

Hofrichter Robert (2017), Tajemnicze życie grzybów, przeł. B. Nowacki, M. Kilis, Warszawa: Prószyński i S-ka.

Janion Maria (2001), Tajemnica sobowtóra, w: M. Janion, Romantyzm i jego media. Prace wybrane, t. 4, Kraków: Universitas.

Kopaliński Władysław (1997), Słownik mitów i tradycji kultury, Lublin.

Macfarlane R. (2016), The Secrets of Wood Wide Web, „The New Yorker”, 7 Aug, https: //www.newyorker.com/tech/elements/the-secrets-of-the-wood-wide-web.

Markowski Andrzej [red.] (2002), Nowy słownik poprawnej polszczyzny, Warszawa.

Referowska-Chodak Ewa (2015), Ludowe zwyczaje zwiazane z grzybami w Polsce, „Studia i Materiały CEPL w Rogowie", z. 44/3, s. 200-217.

Rybicka Elżbieta (2014), Geopoetyka. Przestrzeń i miejsce we wspótczesnych teoriach i praktykach literackich, Kraków: Universitas.

Ryn Zdzisław Jan (2007), Grzyby ułatwiajace kontakt z bogami, https://kultura.onet.pl/ fragmenty-ksiazek/grzyby-ulatwiajace-kontakt-z-bogami/ltd326g.

rozm. Natalia Szostak, „Gazeta Wyborcza” 2018, 28 kwietnia, http://wyborcza.pl/7,75517,23 331310,olga-tokarczuk-w-naszym-swiecie-granica-miedzy-fikcja-a-faktami.html [dostęp 12.10. 2018]. 
Sulima Roch, Grzyb a sprawa polska, rozm. A. Zawisza, „Przegląd” 2010, nr 39, https://www.tygodnikprzeglad.pl/grzyb-sprawa-polska.

Tokarczuk Olga (1997), Nie ma mnie jednej, "Sycyna”, nr 24, s. 3-4.

Tokarczuk Olga (2016), „Gazeta Wyborcza”, 15 września, Czy tożsamość lokalna ma dziś sens?, http://wyborcza.pl/1,87648,20696186,czy-tozsamosc-lokalna-ma-dzis -sens-olga-tokarczuk.html.

Tokarczuk Olga (2018), W naszym świecie granica między fikcją a faktami staje się coraz bardziej płynna, rozm. N. Szostak, "Gazeta Wyborcza”, 28 kwietnia, http:// wyborcza.pl/7,75517,23331310,olga-tokarczuk-w-naszym-swiecie-granica-mied zy-fikcja-a-faktami.html.

Tsing Anna L. (2015), The Mushroom at the End of the World, Princeton: Princeton University Press.

Živković M. (2000), The Double as the „Unseen" of Coulture: toward a Definition of Doppelganger, „Facta Universitatis. Linguistics and Literature”, nr 7, s. 121-128.

https://www.openstreetmap.org/search?query=wodenica\#map=15/50.7159/21.7743

\title{
Mycelium as Metaphor in the Works of Olga Tokarczuk
}

\begin{abstract}
The article concentrates on the motif of fungi which reoccurs in Olga Tokarczuk's novels. The author proves that mycelium functions as epistemological metaphor. It represents the vision of the world based on the interconnectedness, defying dichotomies in this sense. In this Tokarczuk's works represent new humanities - the anthropocentric perspective gives way to a non-anthropocentric one. The author also emphasizes the fact that Tokarczuk's use of mycelium pre-dates the same category introduced by A.L. Tising, who in turn extended the category of rhizome by G. Deleuze and F. Guattari.
\end{abstract}

Keywords: metaphor, mycelium, rhizome, new humanities, non-anthropocentric discourse 